\title{
A Pharmacological Study on the Maintenance of Postural Equilibrium
}

\author{
by \\ Toyoyuki TAMURA, * Hiroshi FURUSAWA, ${ }^{*}$ Masuo AKITA,* \\ Tadahiro ANDO* and Shyuzo KASUYA*
}

\section{Introductory}

In proportion as strides have been made in aviational medicine or space medicine, the concept of the vestibular apparatus is beginning to take on additional importance and its applications are in the form of various anti-train sick drugs commercially available on the market.

In view of ever increasing progress in the air transportation, the study into this direction is considered to be very necessary for the welfare of both pilots and passengers.

Hitherto researches in vertigo and nausea have been more or less confined to the fields of physiology and otorhinology and an attempt from the pharmacological point of view is rather scanty. The present paper deals with a series of tests undertaken on the ordinary commercial drugs which are believed to work favorably for the inhibition of vertigo as well as on these which are concerned with the maintenance of postural equilibrium. It is needless to point out that the occurrence of vertigo at a place of low altitude may be prevented by squatting down but at a high altitude a fall because of vertigo may result in a severe injury. Therefore, efforts were directed to this point with reference to the artificial hibernating agents, chlorpromazine and prometazine (commonly known as anti-shock drugs), \# on their effects on animals that were made to fall from a place of high altitude.

\section{Materials and Method}

\section{Experiment I. Pharmacological Effects on the Postural Maintenance of Concussive Mice.}

A glass vessel of $300 \mathrm{cc}$ content and $70 \mathrm{~mm}$ in diameter was placed on a shaking machine which rotates 240 times per minute over the turntable of $305 \mathrm{~mm}$ in diameter. Male mice of mongrel breed, weighing around $15 \mathrm{~g}$, were placed in the glass vessel following an administration of drugs and were shaken in the horizontal manner for 20 minutes. This shaking process of 20 minutes was thought adequate to generate complete vertigo on the part of experimental mice and having been subjected to the vertigo generation, animal were placed on a glass rod $10 \mathrm{~mm}$ in diameter set horizon-

\footnotetext{
* 田村 豊幸, 古沢 博, 秋田 益夫, 安藤忠広, 槽谷 修三: Dept. of Pharmacology, Nihon Univ. School of Dentistry (Director: Prof. M. Sato)

\# Effect of these drugs upon non-anesthestized resection of upper and lower jaws and tongue were previously reported by the present authors.
} 
tally. The assumptions were that if the pre-medication of anti-vertigo drugs was favorable animals would be able to stay on the rod but otherwise they would sustain a fall. It was brought to light in the process of these tests that there is a stage, before the final postural maintenance on the glass rod, where animals fall when they are made to grasp the rod from the under side. It must be kept in mind with the tests of this kind that animals once on the rod cannot change their position, that is, if they are on the upper side of the rod they remain there, and this is true of those which are made to grasp the rod from the under side.

Table 1 below gives the numbers of fall under five different lengths of shaking time $(5,10,15,20$ and 30 minutes), each repeated ten times so as to calculate the mean values. It is clear that the number of falls sustained by animals increase in proportion to the length of shaking procedure and the figures on Table 1 are graphically represented by Fig. 1.

TABLE 1

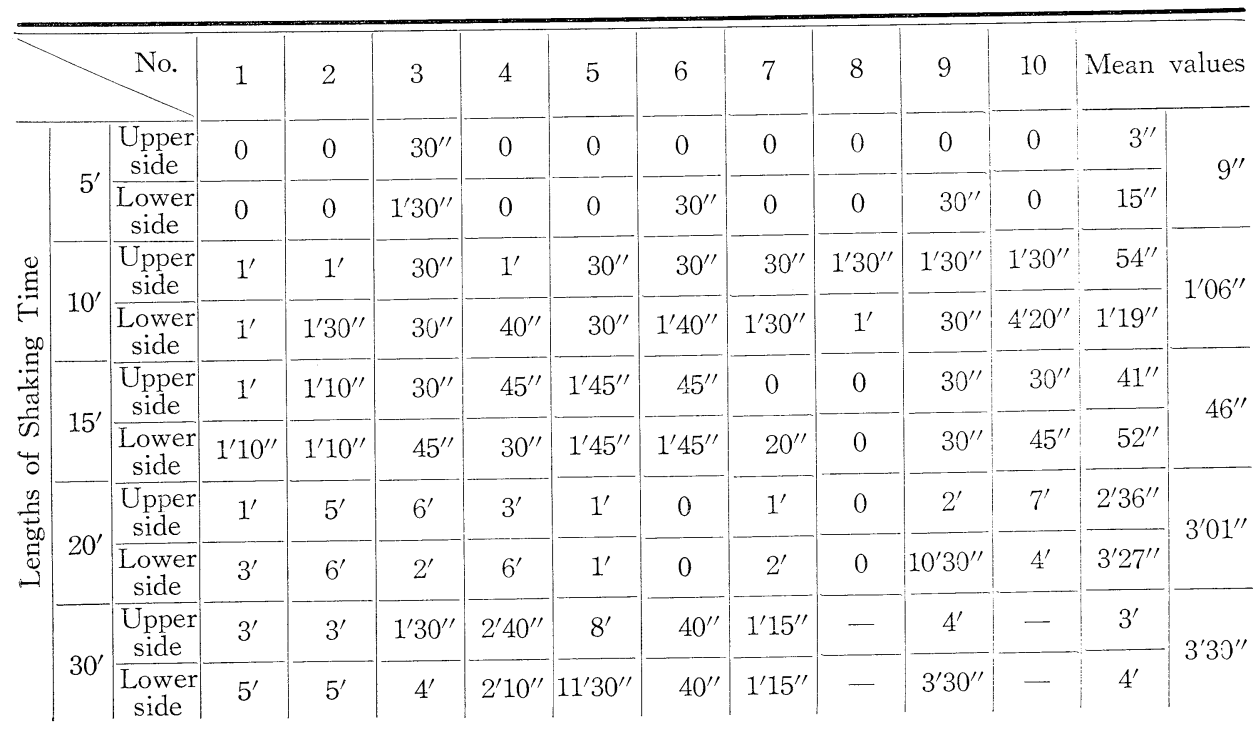

Fig. 1

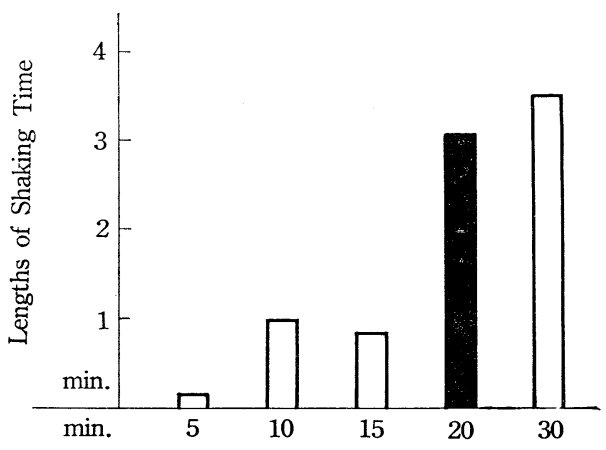


TABLE 2

\begin{tabular}{|c|c|c|c|c|}
\hline & Constituents & $\begin{array}{l}\text { Dosage } \\
\mathrm{mg} / \mathrm{kg}\end{array}$ & Method & $\begin{array}{l}\text { Human } \\
\text { dosage } \\
\text { as unit }\end{array}$ \\
\hline Dramamine & $\begin{array}{l}\text { } \text {-Dimethyl-aminoethylbenzhydrylether, } \\
\text { 8-chlorotheophyllinate } 50 \mathrm{mg}\end{array}$ & 3.3 & Oral & 4 times \\
\hline Bonamine & $\begin{array}{l}\text { 1-p-Chlorobenzhydryl-4-m-methylbenzyl } \\
\text { Piperazine HCl } 25 \mathrm{mg}\end{array}$ & 3.3 & Oral & 7 times \\
\hline Dentomin & $\begin{array}{lr}\text { Chlorpromazine } & 6.25 \mathrm{mg} \\
\text { Promethazine } \mathrm{HCl} & 3.125 \mathrm{mg} \\
\text { Aspirine } & 12.5 \mathrm{mg} \\
\text { Coffeine } & 7.5 \mathrm{mg} \\
\text { Phenacetin } & 25 \mathrm{mg} \\
\text { Phenobarbital } & 7.5 \mathrm{mg}\end{array}$ & 3.3 & Oral & $\begin{array}{c}\text { same } \\
\text { amount }\end{array}$ \\
\hline Meylon & Sodium Bicarbonate & 467.0 & $\begin{array}{c}\text { Cordal } \\
\text { vein }\end{array}$ & 3 times \\
\hline $\begin{array}{l}\text { Crystalline } \\
\text { Dihydrostrepto- } \\
\text { mycin (C. D. S.) }\end{array}$ & 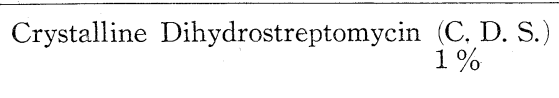 & 67.0 & $\begin{array}{l}\text { Dorsal } \\
\text { injection }\end{array}$ & 2 times \\
\hline
\end{tabular}

Five anti-train sick drugs were selectively employed for these tests (Table 2) and they were pre-medicatively administered half an hour prior to the shaking but, of them only crystalline dihydrostreptomycin was administered for 20 consecutive days before the shaking, the last day of which falling on the start of the test.

Effects of these drugs pre-medicatively used were measured and correlated with the numbers of falls in each group of different shaking lengths (Tables 3, 4 and Figs. $3,4)$. In terms of the average human dosage of which anywhere from 4 to 7 times were used here crystalline dihydrostreptomycin and meylon possess the shortest time before recovery with dramanine coming next, and bonamine and dentomin taking longer time. However, any of the drugs had pronounced effects in inhibiting vertigo when used pre-medicatively. It is an interesting findings that although crystalline dihydrostreptomycin is generally believed to have less equilibrating effects with stronger adverse effect on the auditory organ, we have found the picture reverse and it possesses beneficial effects toward the maintenance of posture. With reference to Dramanine which is commercially marketed as an anti-vertigo agent, effects vary from dosage to dosage and in the present experiment a dosage of $3.3 \mathrm{mg} / \mathrm{kg}$ (which is nearly one thousand times as much as that of humans) was found to have the highest degree of effects, effects becoming less on either side from this dosage.

It must be warned here that in the series of present tests most of the drugs used were administered anywhere from four to ten times the average human dosage while others administered on the basis of human dosage and therefore, it is not possible to compare effects of some drugs with those of others in the same light. It is believed, however, that a new method of examination developed by these tests will serve a useful purpose of exactly determining assumed effects of anti-train sick drugs.

Experiment II. Effects of Chlorpromazine on the Posture Maintenance of Falling Animals and Shocks

A mouse of $17 \mathrm{~g}$, and a rat and a Guinea pig of $200 \mathrm{~g}$ each were artificially 
TABLE 3

\begin{tabular}{c|c|c}
\hline & \multicolumn{2}{|c}{ Dentomin } \\
\hline 1 & $\begin{array}{c}\text { Upper } \\
\text { side }\end{array}$ & $\begin{array}{c}\text { Lower } \\
\text { side }\end{array}$ \\
\hline 2 & $1^{\prime} 25^{\prime \prime}$ & $1^{\prime} 07^{\prime \prime}$ \\
\hline 3 & $41^{\prime \prime}$ & $1^{\prime} 01^{\prime \prime}$ \\
\hline 4 & $1^{\prime} 08^{\prime \prime}$ & $1^{\prime} 53^{\prime \prime}$ \\
\hline 5 & $1^{\prime} 12^{\prime \prime}$ & $2^{\prime} 27^{\prime \prime}$ \\
\hline 6 & $54^{\prime \prime}$ & $1^{\prime} 09^{\prime \prime}$ \\
\hline 7 & $1^{\prime} 01^{\prime \prime}$ & $54^{\prime \prime}$ \\
\hline 8 & $47^{\prime \prime}$ & $1^{\prime} 11^{\prime \prime}$ \\
\hline 9 & $1^{\prime} 00^{\prime \prime}$ & $1^{\prime} 30^{\prime \prime}$ \\
\hline $53^{\prime \prime}$ & $47^{\prime \prime}$ \\
\hline 10 & $41^{\prime \prime}$ & $\frac{1^{\prime} 21^{\prime \prime}}{2}$ \\
\hline Means & $58^{\prime \prime}$ & $1^{\prime} 20^{\prime \prime}$ \\
\hline
\end{tabular}

\begin{tabular}{c|c|c}
\hline & \multicolumn{2}{|c}{ Meylon } \\
\hline 1 & $\begin{array}{c}\text { Upper } \\
\text { side }\end{array}$ & $\begin{array}{c}\text { Lower } \\
\text { side }\end{array}$ \\
\cline { 1 - 2 } & $54^{\prime \prime}$ & $34^{\prime \prime}$ \\
\hline 2 & $1^{\prime} 12^{\prime \prime}$ & $26^{\prime \prime}$ \\
\hline 3 & $46^{\prime \prime}$ & $42^{\prime \prime}$ \\
\hline 4 & $28^{\prime \prime}$ & $38^{\prime \prime}$ \\
\hline 5 & $1^{\prime} 03^{\prime \prime}$ & $50^{\prime \prime}$ \\
\hline 6 & $37^{\prime \prime}$ & $39^{\prime \prime}$ \\
\hline 7 & $53^{\prime \prime}$ & $37^{\prime \prime}$ \\
\hline 8 & $50^{\prime \prime}$ & $41^{\prime \prime}$ \\
\hline 9 & $49^{\prime \prime}$ & $38^{\prime \prime}$ \\
\hline 10 & $51^{\prime \prime}$ & $35^{\prime \prime}$ \\
\hline Means & $50^{\prime \prime}$ & $38^{\prime \prime}$ \\
\hline
\end{tabular}

\begin{tabular}{c|r|r}
\hline & \multicolumn{2}{|c}{ Bonamine } \\
\cline { 2 - 3 } & $\begin{array}{c}\text { Upper } \\
\text { side }\end{array}$ & $\begin{array}{c}\text { Lower } \\
\text { side }\end{array}$ \\
\hline 1 & $52^{\prime \prime}$ & $50^{\prime \prime}$ \\
\hline 2 & $46^{\prime \prime}$ & $1^{\prime} 05^{\prime \prime}$ \\
\hline 3 & $51^{\prime \prime}$ & $1^{\prime} 07^{\prime \prime}$ \\
\hline 4 & $39^{\prime \prime}$ & $1^{\prime} 26^{\prime \prime}$ \\
\hline 5 & $1^{\prime} 23^{\prime \prime}$ & $43^{\prime \prime}$ \\
\hline 6 & $1^{\prime} 06^{\prime \prime}$ & $1^{\prime} 17^{\prime \prime}$ \\
\hline 7 & $53^{\prime \prime}$ & $2^{\prime} 23^{\prime \prime}$ \\
\hline 8 & $41^{\prime \prime}$ & $1^{\prime} 49^{\prime \prime}$ \\
\hline 9 & $1^{\prime} 12^{\prime \prime}$ & $57^{\prime \prime}$ \\
\hline 10 & $59^{\prime \prime}$ & $1^{\prime} 03^{\prime \prime}$ \\
\hline Means & $56^{\prime \prime}$ & $1^{\prime} 16^{\prime \prime}$ \\
\hline
\end{tabular}

\begin{tabular}{|c|c|c|}
\hline & \multicolumn{2}{|c|}{ C. D. S. } \\
\hline & $\begin{array}{l}\text { Upper } \\
\text { side }\end{array}$ & $\begin{array}{c}\text { Lower } \\
\text { side }\end{array}$ \\
\hline 1 & $1^{\prime} 01^{\prime \prime}$ & $20^{\prime \prime}$ \\
\hline 2 & $1^{\prime} 11^{\prime \prime}$ & $9^{\prime \prime}$ \\
\hline 3 & $49^{\prime \prime}$ & $0^{\prime \prime}$ \\
\hline 4 & $58^{\prime \prime}$ & $38^{\prime \prime}$ \\
\hline 5 & $1^{\prime} 23^{\prime \prime}$ & $21^{\prime \prime}$ \\
\hline 6 & $1^{\prime} 07^{\prime \prime}$ & $24^{\prime \prime}$ \\
\hline 7 & $1^{\prime} 05^{\prime \prime}$ & $13^{\prime \prime}$ \\
\hline 8 & $1^{\prime} 14^{\prime \prime}$ & $31^{\prime \prime}$ \\
\hline 9 & $1^{\prime} 02^{\prime \prime}$ & $41^{\prime \prime}$ \\
\hline 10 & $1^{\prime} 10^{\prime \prime}$ & $23^{\prime \prime}$ \\
\hline Means & $1^{\prime} 06^{\prime \prime}$ & $22^{\prime \prime}$ \\
\hline
\end{tabular}

\begin{tabular}{c|c|c}
\hline & \multicolumn{2}{|c}{ Dramamine } \\
\hline 1 & $\begin{array}{c}\text { Upper } \\
\text { side }\end{array}$ & $\begin{array}{c}\text { Lower } \\
\text { side }\end{array}$ \\
\hline 2 & $23^{\prime \prime}$ & $1^{\prime} 16^{\prime \prime}$ \\
\hline 3 & $32^{\prime \prime}$ & $11^{\prime \prime}$ \\
\hline 4 & $36^{\prime \prime}$ & $52^{\prime \prime}$ \\
\hline 5 & $44^{\prime \prime}$ & $48^{\prime \prime}$ \\
\hline 6 & $51^{\prime \prime}$ & $1^{\prime} 33^{\prime \prime}$ \\
\hline 7 & $26^{\prime \prime}$ & $1^{\prime} 08^{\prime \prime}$ \\
\hline 8 & $15^{\prime \prime}$ & $1^{\prime} 20^{\prime \prime}$ \\
\hline 9 & $1^{\prime} 01^{\prime \prime}$ & $1^{\prime} 00^{\prime \prime}$ \\
\hline $53^{\prime \prime}$ & $35^{\prime \prime}$ \\
\hline 10 & $45^{\prime \prime}$ & $1^{\prime} 57^{\prime \prime}$ \\
\hline Means & $38^{\prime \prime}$ & $1^{\prime} 04^{\prime \prime}$ \\
\hline
\end{tabular}

induced to fall from places of varying heights on a windless day and immediately after their fall, $30 \mathrm{mg} / \mathrm{kg}$ of chlorpromazine was intramuscularly injected. This post-medicative group was compared with a group which were injected with the same drug half an hour prior to the fall, the results being correlated. In addition, tails which play 
TABLE 4

Dramamine

\begin{tabular}{|c|c|c|}
\hline & \multicolumn{2}{|c|}{$80 \mathrm{mg} / \mathrm{kg}$} \\
\hline & $\begin{array}{c}\text { Upper } \\
\text { side }\end{array}$ & $\begin{array}{l}\text { Lower } \\
\text { side }\end{array}$ \\
\hline 1 & $\begin{array}{ll}2^{\prime} & 0^{\prime \prime}\end{array}$ & $4^{\prime} 10^{\prime \prime}$ \\
\hline 2 & $1^{\prime} 36^{\prime \prime}$ & $3^{\prime} 17^{\prime \prime}$ \\
\hline 3 & $1^{\prime} 58^{\prime \prime}$ & $57^{\prime \prime}$ \\
\hline 4 & $3^{\prime} 15^{\prime \prime}$ & $6^{\prime} 18^{\prime \prime}$ \\
\hline 5 & $2^{\prime} 05^{\prime \prime}$ & $3^{\prime} 32^{\prime \prime}$ \\
\hline 6 & $2^{\prime} 16^{\prime \prime}$ & $1^{\prime} 55^{\prime \prime}$ \\
\hline 7 & $3^{\prime} 07^{\prime \prime}$ & $1^{\prime} 23^{\prime \prime}$ \\
\hline 8 & $2^{\prime} 31^{\prime \prime}$ & $5^{\prime} 36^{\prime \prime}$ \\
\hline 9 & $2^{\prime} 52^{\prime \prime}$ & $1,45^{\prime \prime}$ \\
\hline 10 & $3^{\prime} 20^{\prime \prime}$ & $5^{\prime} 12^{\prime \prime}$ \\
\hline eans & $2^{\prime} 30^{\prime \prime}$ & $3^{\prime} 14^{\prime \prime}$ \\
\hline
\end{tabular}

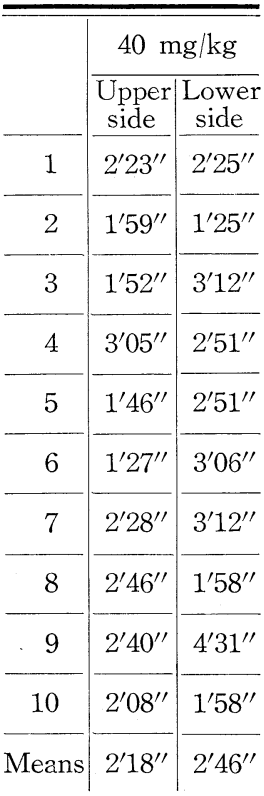

\begin{tabular}{|c|c|c|}
\hline & \multicolumn{2}{|c|}{$20 \mathrm{mg} / \mathrm{kg}$} \\
\hline & $\begin{array}{l}\text { Upper } \\
\text { side }\end{array}$ & $\begin{array}{c}\text { Lower } \\
\text { side }\end{array}$ \\
\hline 1 & $56^{\prime \prime}$ & $2^{\prime} 38^{\prime \prime}$ \\
\hline 2 & $1^{\prime} 15^{\prime \prime}$ & $1^{\prime} 20^{\prime \prime}$ \\
\hline 3 & $1^{\prime} 25^{\prime \prime}$ & $1^{\prime} 12^{\prime \prime}$ \\
\hline 4 & $40^{\prime \prime}$ & $2^{\prime} 07^{\prime \prime}$ \\
\hline 5 & $1^{\prime} 44^{\prime \prime}$ & $56^{\prime \prime}$ \\
\hline 6 & $2^{\prime} 00^{\prime \prime}$ & $3^{\prime} 23^{\prime \prime}$ \\
\hline 7 & $2^{\prime} 26^{\prime \prime}$ & $1^{\prime} 46^{\prime \prime}$ \\
\hline 8 & $1^{\prime} 40^{\prime \prime}$ & $2^{\prime} 16^{\prime \prime}$ \\
\hline 9 & $14^{\prime \prime}$ & $30^{\prime \prime}$ \\
\hline 10 & $1^{\prime} 00^{\prime \prime}$ & $1^{\prime} 23^{\prime \prime}$ \\
\hline eans & $1^{\prime} 20^{\prime \prime}$ & $1^{\prime} 46^{\prime \prime}$ \\
\hline
\end{tabular}

\begin{tabular}{|c|c|c|}
\hline & \multicolumn{2}{|c|}{$7 \mathrm{mg} / \mathrm{kg}$} \\
\hline & $\begin{array}{c}\text { Upper } \\
\text { side }\end{array}$ & $\begin{array}{c}\text { Lower } \\
\text { side }\end{array}$ \\
\hline 1 & $2^{\prime} 28^{\prime \prime}$ & $2^{\prime} 18^{\prime \prime}$ \\
\hline 2 & $1^{\prime} 37^{\prime \prime}$ & $2^{\prime} 03^{\prime \prime}$ \\
\hline 3 & $15^{\prime \prime}$ & $1^{\prime} 23^{\prime \prime}$ \\
\hline 4 & $1^{\prime} 42^{\prime \prime}$ & $1^{\prime} 46^{\prime \prime}$ \\
\hline 5 & $1^{\prime} 34^{\prime \prime}$ & $30^{\prime \prime}$ \\
\hline 6 & $31^{\prime \prime}$ & $1^{\prime} 25^{\prime \prime}$ \\
\hline 7 & $1^{\prime} 20^{\prime \prime}$ & $1^{\prime} 17^{\prime \prime}$ \\
\hline 8 & $1^{\prime} 24^{\prime \prime}$ & $1^{\prime} 31^{\prime \prime}$ \\
\hline 9 & $1^{\prime} 16^{\prime \prime}$ & $45^{\prime \prime}$ \\
\hline 10 & $1^{\prime} 24^{\prime \prime}$ & $1^{\prime} 02^{\prime \prime}$ \\
\hline teans & $1^{\prime} 29^{\prime \prime}$ & $1^{\prime} 24$ \\
\hline
\end{tabular}

\begin{tabular}{|c|c|c|}
\hline & $3.3 \mathrm{n}$ & $\mathrm{ng} / \mathrm{kg}$ \\
\hline & $\begin{array}{c}\text { Upper } \\
\text { side }\end{array}$ & $\begin{array}{c}\text { Lower } \\
\text { side }\end{array}$ \\
\hline 1 & $23^{\prime \prime}$ & $1^{\prime} 16^{\prime \prime}$ \\
\hline 2 & $32^{\prime \prime}$ & $11^{\prime \prime}$ \\
\hline 3 & $36^{\prime \prime}$ & $52^{\prime \prime}$ \\
\hline 4 & $44^{\prime \prime}$ & $48^{\prime \prime}$ \\
\hline 5 & $51^{\prime \prime}$ & $1^{\prime} 33^{\prime \prime}$ \\
\hline 6 & $26^{\prime \prime}$ & $1^{\prime} 08^{\prime \prime}$ \\
\hline 7 & $15^{\prime \prime}$ & $1^{\prime} 20^{\prime \prime}$ \\
\hline 8 & $1^{\prime} 01^{\prime \prime}$ & $1^{\prime} 00^{\prime \prime}$ \\
\hline 9 & $53^{\prime \prime}$ & $35^{\prime \prime}$ \\
\hline 10 & $45^{\prime \prime}$ & $1^{\prime} 57^{\prime \prime}$ \\
\hline eans & $38^{\prime \prime}$ & $1^{\prime} 04^{\prime \prime}$ \\
\hline
\end{tabular}

\begin{tabular}{|c|c|c|}
\hline & \multicolumn{2}{|c|}{$2 \mathrm{mg} / \mathrm{kg}$} \\
\hline & $\begin{array}{c}\text { Upper } \\
\text { side }\end{array}$ & $\begin{array}{c}\text { Lower } \\
\text { side }\end{array}$ \\
\hline 1 & $2^{\prime} 16^{\prime \prime}$ & $2^{\prime} 52^{\prime \prime}$ \\
\hline 2 & $1^{\prime} 17^{\prime \prime}$ & $1^{\prime} 53^{\prime \prime}$ \\
\hline 3 & $57^{\prime \prime}$ & $54^{\prime \prime}$ \\
\hline 4 & $1^{\prime} 19^{\prime \prime}$ & $3^{\prime} 11^{\prime \prime}$ \\
\hline 5 & $1^{\prime} 21^{\prime \prime}$ & $2^{\prime} 04^{\prime \prime}$ \\
\hline 6 & $1^{\prime} 35^{\prime \prime}$ & $1^{\prime} 09^{\prime \prime}$ \\
\hline 7 & $54^{\prime \prime}$ & $2^{\prime} 13^{\prime \prime}$ \\
\hline 8 & $2^{\prime} 27^{\prime \prime}$ & $3^{\prime} 24^{\prime \prime}$ \\
\hline 9 & $1^{\prime} 06^{\prime \prime}$ & $1^{\prime} 10^{\prime \prime}$ \\
\hline 10 & $1^{\prime} 21^{\prime \prime}$ & $2^{\prime} 00^{\prime \prime}$ \\
\hline eans & $1^{\prime} 26^{\prime \prime}$ & $2^{\prime} 04$ \\
\hline
\end{tabular}

\begin{tabular}{|c|c|c|}
\hline & \multicolumn{2}{|c|}{$0.7 \mathrm{mg} / \mathrm{kg}$} \\
\hline & $\begin{array}{c}\text { Upper } \\
\text { side }\end{array}$ & $\begin{array}{c}\text { Lower } \\
\text { side }\end{array}$ \\
\hline 1 & $2^{\prime} 11^{\prime \prime}$ & $41^{\prime \prime}$ \\
\hline 2 & $2^{\prime} 50^{\prime \prime}$ & $33^{\prime \prime}$ \\
\hline 3 & $1^{\prime} 10^{\prime \prime}$ & $1^{\prime} 02^{\prime \prime}$ \\
\hline 4 & $3^{\prime} 11^{\prime \prime}$ & $13^{\prime \prime}$ \\
\hline 5 & $1^{\prime} 53^{\prime \prime}$ & $43^{\prime \prime}$ \\
\hline 6 & $1^{\prime} 07^{\prime \prime}$ & $46^{\prime \prime}$ \\
\hline 7 & $53^{\prime \prime}$ & $44^{\prime \prime}$ \\
\hline 8 & $3^{\prime} 01^{\prime \prime}$ & $1^{\prime} 13^{\prime \prime}$ \\
\hline 9 & $2^{\prime} 04^{\prime \prime}$ & $52^{\prime \prime}$ \\
\hline 10 & $2^{\prime} 00^{\prime \prime}$ & $24^{\prime \prime}$ \\
\hline Ieans & $2^{\prime} 02^{\prime \prime}$ & 42 \\
\hline
\end{tabular}

an important role in the postural maintenance mechanism of animals were cut off either at the root or in the middle and their effects in the posture equilibrium were investigated. 
Fig. 2

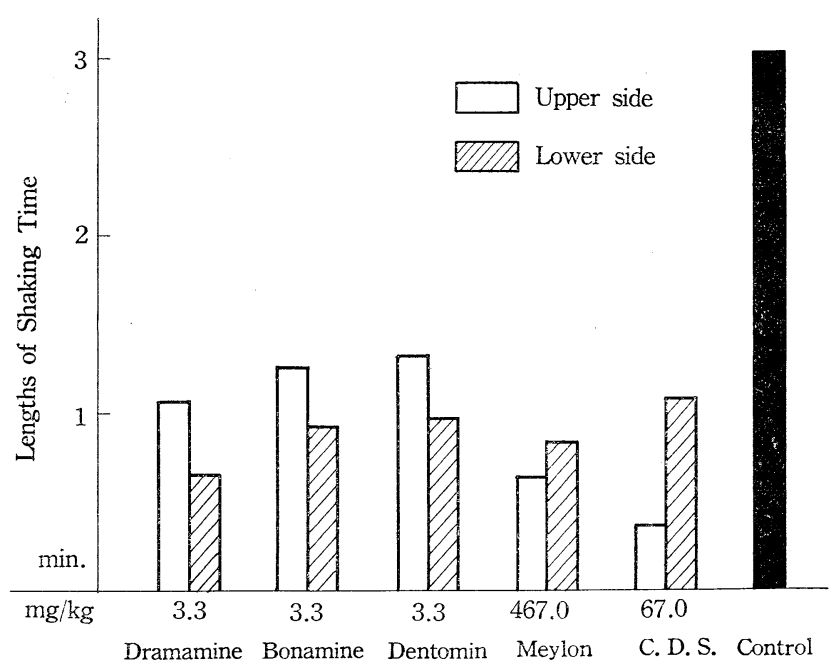

Fig. 3

Dramamine

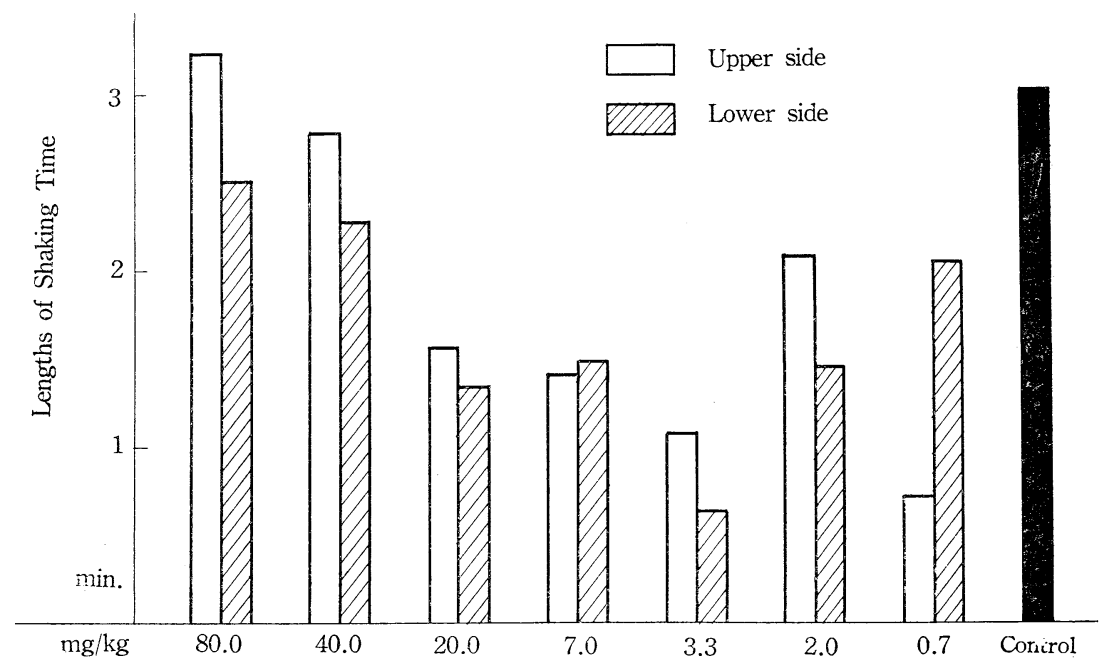

Table 5 gives findings on the fall of animals. It was generally found that the cutting off of tail at the root had more adverse effects in keeping postural equilibrium than in the middle, some of animals coming to die in a few minutes after a fall. At any rate, those animals whose tails were cut off suffered a higher rate of death than others and this is to be accounted for by various factors not only by defect in keeping postural equilibrium, but also resistance against air, shock at landing etc. An animal with a sound tail is observed to fall with its limbs spreading and tail straight so that the resistance against air may be maximum. On the other hand, a tailless animal 
cannot sufficiently keep his body in equilibrium by its limbs alone and usually falls in a tail-spin fashion.

TABLE 5

\begin{tabular}{|c|c|c|c|c|}
\hline \multirow[b]{2}{*}{ Heights of fall } & \multirow[b]{2}{*}{$\begin{array}{l}\text { No. of survival } \\
\text { after } 24 \text { hours }\end{array}$} & \multicolumn{3}{|c|}{ Number of deaths } \\
\hline & & $\begin{array}{l}\text { Within a few } \\
\text { minutes after } \\
\text { landing }\end{array}$ & $\begin{array}{l}\text { Within } \\
24 \text { hours }\end{array}$ & Total \\
\hline $8 \mathrm{~m}$ & 9 & 1 & 0 & 1 \\
\hline $10 \mathrm{~m}$ & 8 & 1 & 1 & 2 \\
\hline $12 \mathrm{~m}$ & 8 & 2 & 0 & 2 \\
\hline $16 \mathrm{~m}$ & 6 & 3 & 1 & 4 \\
\hline $\begin{array}{l}16 \mathrm{~m} \\
\text { (Tail half cutting) }\end{array}$ & 0 & 9 & 1 & 10 \\
\hline $\begin{array}{l}16 \mathrm{~m} \\
\text { (Tail total cutting) }\end{array}$ & 0 & 10 & 0 & 10 \\
\hline $\begin{array}{l}16 \mathrm{~m} \text { Chlorpromazine } \\
\text { (Pre-medication) }\end{array}$ & 9 & 8 & 1 & 9 \\
\hline $\begin{array}{l}16 \text { m Chlorpromazine } \\
\text { (Post-medication) }\end{array}$ & 8 & 2 & 0 & 2 \\
\hline Total & 40 & 4 & 4 & 40 \\
\hline
\end{tabular}

When chlorpromazine was pre-medicatively given, it tended to work adversely on the equilibrium mechanism because the drug contained a certain function of relaxing muscles but when used post-medicatively immediately following a fall, it was found to work beneficially and checked the number of deaths by half. Anatomical observations of the animals which died upon landing revealed a bigh degree of hemorrhage due to disruption of liver, bone fracture and hemorrhage of the basilar region of skull, pulmonary hemorrhage, hypodermal hemorrhage, disruption of other internal organs and cutting of veins among other things. Of those which came to die in twenty-four hours, the irregularities were confined to the fracture of pelvis, hemorrhage of meninges and ventral hemorrhage. If there were others, it was not possible for the naked eye to detect them. In comparison with mice, the findings relative to rats gave a higher rate of death as they could not keep their posture in equilibrium regardless of tail or otherwise, even on with a sound tail dying upon landing instantaneously. The anatomical findings were almost identical to those of mice referred to above. Lastly, Guinea pigs seem to have least resistance to this kind of fall as against mice and rats. When they were made to fall from a height of 10 meters, all the subjects died and their anatomical findings differed from others in that the large intestines and kidneys were disrupted. When they died, they took shorter time than either mice or rats.

\section{Summary}

Mice and similar subjects were used in a series of tests where they were placed in a shaking apparatus of simple mechanism and the state of being train-sick was artificially generated. They could not grasp a glass rod immediately after this state but when anti-train drugs were pre-medicatively administered, the time before they 
recovered an ability to grasp the rod was much reduced. From this, it has been established that the use of a shaking apparatus and a glass rod proves effective in an examination of effects attributed to these anti-train sick agents which are now commercially available.

In this connection, it was also found out that effects of chlorpromazine which is accepted as anti-shock agent work adversely on the generation of vertigo in the case of a fall. It is thought that the study on this subject furnishes a useful insight in the training of personnel engaged in the air transportation where they are faced with the necessity of parachuting down from a considerable height.

It may be added that a part of the present report was read before the Tokyo meeting of 23rd Japan Pharmacological Society Congress, held in November 1961.

\section{References}

[1] Cooper, J. S. : Anterior Chroidal Artery Ligation for Involuntary Movement, Science, 118 (1953).

[2 2 Grundfest, H. and CARTER, W. B. : Afferent Relation of Inferior Olivary Muscles, 1. Electrophysiological Demonstration of Dorsal Spinal-Olivary Tract in Cat, J. Neurophysicl., 17 (1954).

[3] Siegrried, R.: On the Need of Aviation Medicine, National Defence Medical Journal, 8 (1961).

[4] Kusuda, E. et al. : Clinical Observations on the Streptomycin Complications (in Jap.), The Sapporo Medical J., 12 (1957).

[5] Sato, S. et al. : An Experimental Pharmacological Study on the Adverse Effects of Streptomycin upon Auditory Organ (in Jap.), Jap. J. Otol., 61 (1958).

[6] Suzuki, Y.: A Few Clinical Findings of an English Anti-Poison Agent BAL on the Auditory Defect due to Streptomycin. (in Jap.), Jap. J. Otol., 61 (1958).

[7] Egawa, T. et al.: The Auditory Difficulty of Streptomycin and Chondroitin (in Jap.), Jap. J. Otol., 61 (1958).

[ 8] Sita, T. : On the Generation of Auditory Difficulty due to Dihydrostreptomycin (in Jap.), Jap. J. Otol., 61 (1958).

[9] Nosaka, Y. : An Alinamin Treatment for Neurotic Hearing Difficulties (in Jap.), Jap. J. Otol., 61 (1958).

[10] NoIRI, T.: The Influence of Acceleration Rotation Stimulation on Serum Potassium, Jap. J. Otol., 61 (1956).

[11] TAmUra, T. : Relation between Shocks due to Jaw-Resection and Glossectomy and AntiShock Drugs, J. Nihon U. S. D., 1 (1959). 